\title{
RESEARCH ON INTERNAL INDICATORS OF FINANCIAL STABILITY OF INSURANCE COMPANIES IN THE REPUBLIC OF SERBIA
}

\author{
Tatjana Stevanović* \\ Faculty of Economics, University of Niš, Niš, Republic of Serbia \\ Jelena Stanković \\ Faculty of Economics, University of Niš, Niš, Republic of Serbia \\ Jovica Stanković \\ Faculty of Economics, University of Niš, Niš, Republic of Serbia
}

\begin{abstract}
Dynamic changes in the insurance sector require a new system of performance measures, which enables monitoring of multiple business segments of insurance companies and meets the information requirements of a large number of different stakeholders. In this regard, in the Republic of Serbia a multidimensional system of performance measures is used - the CARMEL framework, made according to the methodology of the International Monetary Fund. Due to the fact that these indicators indicate the effectiveness of different business segments, the analysis of the performance of insurance companies cannot be based only on one of these groups. Assessment of financial stability and ranking of insurance companies can be performed using different data mining algorithms. The obtained results show that key internal factors for the financial stability of insurance companies change under different economic conditions. During the period of the financial crisis the greatest impact on the financial stability of insurance companies had the quality of management, but also the earning capacity and profitability and liquidity of insurance companies. The classification of insurance companies according to their performance is compared with the official rankings offered by the supervisory body based on the value of the balance sheet assets and the value of premiums paid. It can be concluded that the largest insurance companies are not the most successful in all economic conditions. Inadequate capital management, as well as the inability to generate insurance and investment portfolios, has led to a drastic decrease in the profitability of these insurance companies.
\end{abstract}

Key words: insurance, financial stability, CARMEL, principal component analysis, cluster analysis

\footnotetext{
*tatjana.stevanovic@ekonomski.rs
} 


\title{
ISTRAŽIVANJE INTERNIH INDIKATORA FINANSIJSKE STABILNOSTI OSIGURAVAJUĆIH DRUŠTAVA U REPUBLICI SRBIJI
}

\begin{abstract}
Sažetak: Dinamične promene u sektoru osiguranja zahtevaju novi sistem mera performansi, koji omogućava monitoring većeg broja segmenata poslovanja društava za osiguranje i zadovoljava različite informacione potrebe velikog broja stejkoholdera. U skladu sa tim, u Republici Srbiji se primenjuje multidimenzionalni sistem mera performansi - CARMEL okvir, koji je definisan u skladu sa metodologijom Međunarodnog monetarnog fonda. S obzirom na to da ovi indikatori ukazuju na efikasnost različitih poslovnih segmenata, analiza performansi društava za osiguranje se ne može bazirati samo na jednoj grupi pokazatelja. Ocena finansijske stabilnosti $i$ rangiranje osiguravajućih društava može se izvršiti upotrebom različitih algoritama za rudarenje podataka. Dobijeni rezultati pokazuju da se ključni interni faktori finansijske stabilnosti ovih društava menjaju u različitim ekonomskim uslovima. Tokom perioda finansijske krize najveći uticaj na finansijsku stabilnost imali su kvalitet menadžmenta, kao $i$ profitabilnost $i$ likvidnost osiguravajućih društava. Klasifikacija društava za osiguranje prema ostvarenim performansama je upoređena sa zvaničnim rangiranjem koje vrši nadzorno telo na osnovu vrednosti imovine $i$ ostvarenih premija. Može se zaključiti da najveća osiguravajuća društva nisu i najuspešnija u svim ekonomskim uslovima. Neadekvatno upravljanje kapitalom, kao $i$ nemogućnost generisanja investicionog portfolia $i$ portfolia osiguranja, dovode do drastičnog smanjenja profitabilnosti ovih društava.
\end{abstract}

Ključne reči: osiguranje, finansijska stabilnost, CARMEL, analiza glavnih komponenata, klaster analiza

\section{INTRODUCTION}

Insurance as a form of organized protection, which role is to ensure the security, trust and protection of people's property and lives, is becoming a dominant risk management strategy in the face of global change, especially in developing countries (Linnerooth-Bayer \& Mechler, 2015). However, numerous anomalies can be observed in the functioning of the insurance market, both on the supply side and on the demand side for insurance. In the underdeveloped markets and in the insurance markets which are in the process of development, anomalies are more pronounced, but unlike developed markets, in general, the economies of 
developing countries have seen significant growth rates over the past two decades and have shown some resilience to shocks. By creating a stimulating economic environment and improving insurance regulations, they have maintained a continuous increase in insurance premiums, even in the 2007/2008 crisis and the role of insurance in the financial sector, as well as its importance for the economic well-being of society, has increased. Despite the fact that developing economies account for $19.7 \%$ of the world insurance market, these fast-growing, but largely specific markets, are of particular importance for the development of insurance. Considering the influence of macroeconomic determinants on the development of the insurance market and importance of emerging insurance markets (Petrović \& Stanković, 2018), the subject of this paper will be to determine the internal factors of business success of insurance companies in the Republic of Serbia. Therefore, the aim of this paper is twofold: on the one hand, this study will analyse internal factors of business success of insurance companies in different economic conditions in order to identify the key factors, while on the other hand, identified business performance indicators will be used to rank the insurance companies which operated in the observed period on the territory of the Republic of Serbia. Accordingly, the main hypothesis of this research study is:

$\mathrm{H}_{0}$ : The observed insurance companies can be divided into clusters according to the achieved degree of financial stability in the period before the financial crisis, during the crisis and in the post-crisis period.

Thus, the alternative hypothesis can be defined in the following manner:

$\mathrm{H}_{\mathrm{a}}$ : The observed insurance companies cannot be divided into clusters according to the achieved degree of financial stability in the period before the financial crisis, during the crisis and in the post-crisis period.

However, performance measurement is a complex concept both in terms of choice of measures and in terms of their quantification. In an informationintensive branch, such as insurance, an adequate mix of different indicators is a very important impulse to motivate and measure the performance of business units (Cummins, Dionne, Gagné \& Nouira, 2009). On the other hand, the different information needs of a large number of stakeholders in insurance companies make business considerations different. Research based on concrete examples has shown that insurance companies are actively considering key success factors and choosing the right system of performance measures as the basis of strategic and operational control (Kaplan \& Norton, 2001; Banker, Janakiraman \& Konstans, 2001; Ittner, Larcker \& Randall, 2003). In this paper, the financial stability assessment of insurance companies is based on internal business success factors, which are quantitatively presented using the CARAMELS framework indicators. The set of basic and supplementary 
4 | RESEARCH ON INTERNAL INDICATORS OF FINANCIAL STABILITY OF INSURANCE COMPANIES IN THE REPUBLIC OF SERBIA

indicators for life and non-life insurance is defined in accordance with the methodology of the International Monetary Fund (IMF) (Das, Podpiera \& Davies, 2003) and is used in the Republic of Serbia to monitor and analyze the financial stability of insurance companies. However, as in certain emerging economies (Smajla, 2014), the National Bank of Serbia (NBS) does not use a complete set of indicators but an abbreviated CARMEL framework (NBS, 2016). Due to the fact that these indicators indicate the strength of different business segments, business performance analysis cannot be based on just one group of them. A number of indicators in this paper are grouped into appropriate composite indicators, applying principal component analysis, whose structure and significance change depending on the economic conditions in which insurance companies operate. Based on the indicators formed in this way, the assessment and ranking of insurance companies was performed using a classification model. Cluster analysis is one of the main classification techniques and it is very often applied in the analysis of large data sets. In this paper, cluster analysis is used to look at the financial position of insurance companies in the period 2005-2015. Because of the fact that in the Republic of Serbia NBS as an insurance supervisor does not provide a comprehensive view of the performance of insurance companies, and ranks insurance companies only on the basis of the paid insurance premium and balance sheet sum, the analyzes based on multidimensional system of performance presented in this paper have both theoretical and practical significance for development of insurance in emerging markets, such as the insurance market of the Republic of Serbia.

In the continuation of the paper, the current methodologies for assessing the financial stability of the business of insurance companies will be discussed, while the third part of the paper describes the methodology of research, as well as an analysis of the business of insurance companies in the Republic of Serbia conducted on the basis of CARMEL indicators. The calculated indicator values represent variables that will be used in the principal component analysis and then in the cluster analysis. The results obtained will be presented in the fourth part of the paper, while the last part will conclude and outline directions for future research.

\section{LITERATURE REVIEW}

Financial performance of insurance companies is usually expressed in earned net premiums, profitability of insurance activities, and rate of return on investment, return on equity, etc. These measures can be classified as measures of profit performance and measures of investment success. However, the performance of this sector includes both financial and non-financial areas of 
business. Profit performance refers to profit expressed in monetary terms, as the difference between income and expense. Some of the non-financial performance measures may include policy number growth, affiliate or division market share locally, insurance company market share as a whole, number of affiliates or divisions, policy processing speed, claim resolution rate, timely notification of users, product growth and product lines, customer satisfaction, employee training, research and development, market intelligence and surveys, number of policies per agent, agent training, retention of effective agents, etc. (Banker, Janakiraman \& Konstans, 2001; Kaplan \& Norton, 2001; Kasturi, 2006).

Based on the Solvency and Financial Reporting Reports of the company for non-life insurance in the European Union and the Baltic markets in 2016, Zarina, Voronova and Pettere (2018) analyzed historical market development and calculated financial indicators, the Gini index of concentration, and the index of diversity. In their survey, they summarized the stability statistics on solvency coefficients, risk profiles and capital surplus. The authors examined current and future internal and external risks and problems in the non-life insurance market in the Baltic region, such as the political environment, lowincome environment and market competition, due to new mergers and acquisitions activities, as well as the new rule for the accounting of insurance companies IFRS17. Lee and Lin (2016) investigated the impacts of the operational environment (globalization, political institutions, and financial liberalization) on the performance and risk taking of insurance organizations from an international perspective. Increased globalization and stable political institutions lead to better performance of insurance companies, but financial liberalization has an adverse impact on insurance company performance. Lee, Chang, Arouri and Lee (2016) have investigated how institutional environments affect the relation between insurance and economic growth. Using multiple general measures related to political, economic, and legal environments (rule of law, legal structure, and security of property rights) to assess the adequacy of institutional environments, they have noticed that the relation between life insurance and economic growth is negative in the conditions of the relatively unhealthy institutional environments. However, this negative effect becomes insignificant after a certain level of institutional quality has been achieved. This result might be explained by the problem of adverse selection and moral hazard, the behaviour of risk-taking, and macroeconomic volatility.

Applying an advanced panel threshold regression model, Yu (2015) examined the impact of free cash flow, leverage and dividend policy on firm performance of enterprises in the U.S. insurance industry. The results indicated that, based on an optimal ratio or optimal ratio regime, U.S. insurance companies increase debt 
6 | RESEARCH ON INTERNAL INDICATORS OF FINANCIAL STABILITY OF INSURANCE COMPANIES IN THE REPUBLIC OF SERBIA

and dividend issuance and thus, improve firm performance and solve financial problems.

Previous studies also concentrate on the effects of organizational factors and customers' motivation on insurance companies' performance and analyze the influence of companies' age, size, and type of products in the research model in Portuguese and Spanish markets (Felício \& Rodrigues, 2015). Results show that needs of customers and confidence significantly affects organizational factors, which in turn affect the insurance company performance. Organizational and customers' motivation factors improve performance of insurance companies, depending on companies' activities. Camarero (2007) also analyzes the effects of complementary relationship and service-quality orientations on market and economic performance. Results point that relational applying policies such as communication, preferential treatment, and adaptation to customers' needs is critical for customer retention, reducing complaints and conflicts or improving the positioning.

In today's dynamic business world, it is necessary that life insurance companies focus on changes in operating performance over long time periods. The capital allocation and planning processes are essential for life insurance companies. Lu, Wang \& Kweh (2014) evaluated the performance of Chinese life insurance companies for the period 2006-2010. This study examines the relationship between intellectual capital and performance and indicates that the primary efficiency scores of life insurers are relatively stable. Regression analysis in this study indicates that intellectual capitals are significantly positively associated with firm operating efficiency. Consequently, in this dynamic business world, life insurers' managers should invest and fully utilize intellectual capital to reach a competitive advantage.

The earlier empirical literature has mostly relied on investigating the factors that mostly affect financial performance. Thus, Almajali, Alamro and Al-Soub (2012) investigated the factors that determine the financial performance of Jordanian Insurance Companies. The results suggest that the variables like leverage, liquidity, size, management competence index, have a positive statistical effect on the financial performance of Jordanian Insurance Companies. So, the research found that a high consideration of increasing the company assets provides good financial performance. They recommended placing highly qualified employees in the top managerial staff. Similarly, Malik (2011) investigated the effects of specific factors (age of company, size of company, volume of capital, leverage ratio and loss ratio) on profitability (return on assets) in the insurance companies of Pakistan. The results indicate that there is no association between age and profitability of the company and there is a significantly positive relationship between size of the company and 
profitability. Also, there is a positive relationship between the volume of capital and profitability. Finally, loss ratio and leverage ratio showed a negative but significant relationship with profitability. Similar research related to the insurance companies in India. So, Bawa and Chattha (2013) determine the impact of liquidity, solvency, leverage, size and equity capital on the profitability of life insurers. The results of the study show that profitability of life insurers is positively influenced by size and liquidity and negatively related with capital. Also, profitability does not show any relationship with insurance solvency and leverage.

Lillian (2010) analyzes the relationship between corporate governance, ownership structure and financial performance of insurance companies in Kenya. The research showed a significant relationship between size, nonexecutive directors and leverage with both Return on Assets and Return on Equity. Also, the study found that board size and constitution and financial leverage have a significant impact on both return on equity and return on assets. Finally, this study found that the relationship between ownership and financial performance of insurance companies was insignificant.

Taking into account the availability of information on the business of insurance companies and the specificities of the developing insurance market, this paper will analyze the internal factors of financial stability of insurance companies by applying the adopted CARMEL framework of ratio numbers, which will be described in detail below.

\section{RESEARCH METHODOLOGY}

\subsection{RESEARCH SAMPLE}

The research sample in this study consists of the insurance companies that operate in the territory of the Republic of Serbia. The number of insurance and reinsurance companies in Serbia increased in the observed period - from 19 in 2005 , to 26 in 2010, and finally 24 in 2015, which led to a decrease in concentration of portfolios in the market (NBS, 2017). Considering the structure of the insurance portfolio, it can be concluded that the carriers of the development of the insurance market in the Republic of Serbia are non-life insurance companies and are mostly privately owned. DDOR Novi Sad, Generali Insurance, Dunav Insurance and Wiener Stadtische Insurance are the largest insurance companies in the Republic of Serbia, which accounted for $70.8 \%$ of the total premium in 2015 , as it can be observed from the rankings provided by NBS (See Table 1). 
8 | RESEARCH ON INTERNAL INDICATORS OF FINANCIAL STABILITY OF INSURANCE COMPANIES IN THE REPUBLIC OF SERBIA

Table 1

Ranking of insurance companies in the Republic of Serbia in 2005, 2010 and 2015

\begin{tabular}{lccccccc}
\hline \multirow{2}{*}{$\begin{array}{l}\text { Insurance company } \\
\text { Dunav Insurance }\end{array}$} & $\begin{array}{l}\text { Ranks according to } \\
\text { the value of earned } \\
\text { insurance premium }\end{array}$ & \multicolumn{2}{c}{$\begin{array}{c}\text { Ranks according to } \\
\text { the value of asset }\end{array}$} \\
\cline { 2 - 8 } & $\mathbf{2 0 0 5}$ & $\mathbf{2 0 1 0}$ & $\mathbf{2 0 1 5}$ & $\mathbf{2 0 0 5}$ & $\mathbf{2 0 1 0}$ & $\mathbf{2 0 1 5}$ \\
\hline DDOR Novi Sad & 1 & 1 & 1 & 1 & 1 & 2 \\
\hline Generali Insurance & 2 & 2 & 3 & 2 & 3 & 5 \\
\hline Wiener Stadtische Insurance & 3 & 3 & 2 & 3 & 2 & 1 \\
\hline
\end{tabular}

Note. NBS annual reports "Insurance sector in Serbia" for the year 2005, 2010 and 2015

This paper analyses in detail the financial performance of the operations of 14 insurance companies operating in the Republic of Serbia during 2005, 2010 and 2015, as follows: (1) in the life insurance sector: SAVA life insurance, Uniqa life insurance; (2) in the non-life insurance sector: SAVA Insurance, AMS Insurance, Globos Insurance, Millennium Insurance, Uniqa Non-Life Insurance, Energoprojekt Garant Insurance, and (3) 6 mixed insurance companies that deal with both life and non-life insurance: Grawe Insurance, Triglav Insurance, DDOR Novi Sad, Generali Insurance, Dunav Insurance and Wiener Stadtishe Insurance.

\subsection{DATA SOURCES AND RESEARCH VARIABLES}

The effective operating and risk management of insurance companies is crucial to the efficiency of the financial system as a whole. In this regard, the NBS has defined a set of criteria for the quantitative monitoring and analysis of the financial stability of insurance companies, modelled on the IMF methodology. The NBS Decision on the Management System of an (Re) Insurance Company $(2015,2018)$ provided a framework for practical steps towards risk management in the insurance sector, while CARMEL indicators could be used as one of the risk management instruments. CARMEL indicators fall into six basic groups: capital adequacy, asset quality, reinsurance and actuarial issues, management soundness, earnings and profitability and liquidity. Each of these groups can be further subdivided into several sub-groups, both for life and non-life business insurance. The indicators used in this analysis are shown in Table 2. 
Table 2

Financial stability indicators of insurance companies

\begin{tabular}{|c|c|c|}
\hline Indicator & Symbol & Calculation \\
\hline \multirow{3}{*}{ Capital Adequacy } & $\mathrm{C} 1$ & Retained premium / Total capital \\
\hline & $\mathrm{C} 2$ & Total capital / Total Assets \\
\hline & $\mathrm{C} 3$ & Total capital / Technical reserves \\
\hline \multirow{3}{*}{ Asset Quality } & A1 & $\begin{array}{l}\text { (Intangible Assets }+ \text { Real Assets }+ \text { Securities }+ \\
\text { Receivables) / Total Assets }\end{array}$ \\
\hline & $\mathrm{A} 2$ & Receivables from insureds / Total contracted premium \\
\hline & A3 & Equity Investments / Total Assets \\
\hline $\begin{array}{l}\text { Reinsurance and } \\
\text { Actuarial Issues }\end{array}$ & R1 & $\begin{array}{l}\begin{array}{l}\text { Reference retained premium } \\
\text { premium }\end{array} \\
\text { p Reference total }\end{array}$ \\
\hline $\begin{array}{l}\text { Management } \\
\text { Soundness }\end{array}$ & M3 & Salaries / Retained premium \\
\hline \multirow{3}{*}{$\begin{array}{l}\text { Earnings and } \\
\text { Profitability }\end{array}$} & E4 & $\begin{array}{l}\text { (Reference retained claims / Reference retained } \\
\text { premium })+(\text { Costs of Insurance / Reference retained } \\
\text { premium })\end{array}$ \\
\hline & E5 & $\begin{array}{l}\text { E4 - (Investment Income / Reference retained } \\
\text { premium) }\end{array}$ \\
\hline & E8 & Net Result / Total Capital \\
\hline \multirow{2}{*}{ Liquidity } & L1 & Cash and Cash Equivalents / Current Liabilities \\
\hline & $\mathrm{L} 2$ & (Current Assets - Supplies) / Current Liabilities \\
\hline
\end{tabular}

Note. NBS (2016). CARMEL indicators of insurance companies' operations with the framework guidelines for their interpretation. Belgrade: National Bank of Serbia.

To calculate the CARMEL indicators, financial statements of insurance companies, which are publicly available on the website of the Agency for Business Registers of the Republic of Serbia (http://www.apr.gov.rs/) and reports on business operations of insurance companies, available on the NBS website (http://www.nbs.rs), were used. Because of the fact that segment reporting in mixed life and non-life insurance companies is not informative to the extent that it would allow the calculation of all CARMEL framework indicators, the performance assessment of these companies was based on composite indicators.

Based on the disclosed data, 13 indicators were calculated and descriptive statistics are presented in the tables that follow.

\subsection{DESCRIPTIVE STATISTICS}

Indicators of capital adequacy are key indicators of the financial stability of insurance companies, due to the fact that capital has the function of absorbing risks in the operations of these companies. The very high value of this indicator 

COMPANIES IN THE REPUBLIC OF SERBIA

(an average of $228.40 \%$ in 2010 , and $201.77 \%$ in 2015) is dominant in mixed life and non-life insurance companies, indicating that this combined business provides the best opportunities to form an optimal insurance portfolio. The relatively low values of $\mathrm{C} 2$ indicator with a declining tendency indicate high exposure of insurance companies to the market, investment and credit risk. Mixed insurance companies are more exposed to the risks, with the average value of C2 indicators in 2010 being $20.07 \%$ and $23.14 \%$ in 2015, respectively. The value of indicator $\mathrm{C} 3$ indicates the decline in the relative level of capitalization of insurance companies in the Republic of Serbia. At the same time, mixed insurance companies are characterized by a very low value of this indicator (on average $30.02 \%$ in 2010 and $49.49 \%$ in 2015). There is a marked drop in capitalization in life insurance companies (average value of C3 indicators in 2010 was $605.25 \%$ and in 2015 93.94\%), while non-life insurance companies keep the level of C3 indicators above $100 \%$ throughout the whole period (See Table 3).

The Asset Quality Indicators Group provides insight into the degree of diversification of placements into different types and forms of assets and dispersion of placements in the assets of different clients, which contributes to the financial stability of insurance companies, as it reduces the uncertainty of their liquidity and, consequently, reduces the likelihood of companies defaulting on insurance. However, the average value of indicators from this group indicates an inadequate way of managing market, investment and credit risk. During the observation period, cyclical movements in the value of this indicator can be observed in line with developments in the financial market. Thus, in the crisis period (2010), its average value was reduced to $25.3 \%$, while in the period after the crisis (2015), the share of these types of assets increased to an average of $35.6 \%$ (in life insurance and up to $60 \%$ ). At the same time, the value of indicator A2 decreased, indicating an increased level of collection of premium claims, while the value of shares in the investment portfolio of insurance companies decreased since the dominant share is taken over by real estate investing (Kočović, Paunović \& Jovović, 2014).

The value of R1, shown in Table 3, indicates that insurance companies operating in the Republic of Serbia have a conservative reinsurance policy, retaining on average more than $80 \%$ of the assumed insurance risks in their portfolio. The average value of this indicator in the life insurance sector is over $90 \%$. The non-life insurance sector recorded the value of this indicator approximately the same as the overall average of $75.1 \%$ in $2005,84.8 \%$ in 2010 and $87.8 \%$ in 2015 , while the average value of this indicator in mixed insurance companies was $69.5 \%$ in $2005,87.1 \%$ in 2010 and $83.5 \%$ in 2015. 
Table 3

Descriptive statistics of indicators of insurance companies in the Republic of Serbia in 2005, 2010 and 2015

\begin{tabular}{|c|c|c|c|c|c|c|c|c|c|}
\hline \multirow{2}{*}{ Indicators } & \multicolumn{4}{|c|}{$\mathbf{2 0 0 5}$} & \multicolumn{3}{c|}{$\mathbf{2 0 1 0}$} & \multicolumn{3}{|c|}{$\mathbf{2 0 1 5}$} \\
\cline { 2 - 11 } & No. & Mean & St.dev & No. & Mean & St.dev & No. & Mean & St.dev \\
\hline C1 & 12 & 1.22 & 0.87 & 14 & 1.75 & 1.08 & 14 & 1.91 & 1.29 \\
\hline C2 & 12 & 0.48 & 0.19 & 14 & 0.32 & 0.22 & 14 & 0.25 & 0.20 \\
\hline C3 & 12 & 1.69 & 1.91 & 14 & 1.56 & 3.12 & 14 & 0.84 & 1.47 \\
\hline A1 & 12 & 0.35 & 0.21 & 14 & 0.25 & 0.15 & 14 & 0.36 & 0.25 \\
\hline A2 & 12 & 0.24 & 0.15 & 14 & 0.19 & 0.10 & 14 & 0.11 & 0.09 \\
\hline A3 & 12 & 0.17 & 0.22 & 14 & 0.06 & 0.12 & 14 & 0.01 & 0.02 \\
\hline M3 & 12 & 0.08 & 0.04 & 14 & 0.13 & 0.21 & 14 & 0.07 & 0.07 \\
\hline R1 & 12 & 0.72 & 0.12 & 14 & 0.88 & 0.13 & 14 & 0.88 & 0.12 \\
\hline E4 & 12 & 0.83 & 0.17 & 14 & 1.14 & 0.77 & 14 & 0.89 & 0.24 \\
\hline E5 & 12 & 0.76 & 0.25 & 14 & 1.01 & 0.83 & 14 & 0.97 & 0.93 \\
\hline E8 & 12 & 0.11 & 0.13 & 14 & 0.03 & 0.18 & 14 & -0.01 & 0.22 \\
\hline L1 & 12 & 0.37 & 0.39 & 14 & 0.36 & 0.35 & 14 & 0.28 & 0.30 \\
\hline L2 & 12 & 1.99 & 1.72 & 14 & 2.91 & 3.40 & 14 & 8.70 & 16.05 \\
\hline
\end{tabular}

Note. Authors' calculations.

Operational risks occupy a significant place in the group of factors that affect the financial stability of insurance companies, as inadequate internal processes, employees and the system can critically contribute to insurer insolvency. If the movement of values of these indicators is viewed from period to period, it can be concluded that the quality of management has continuously increased, especially in life insurance, accompanied by rational use of resources and better organization.

Profitability indicators based on accounting data indicate a low level of profitability of insurance companies, since the average rate of return on total capital (E8) decreased in the observed period. Mixed insurance companies, whose average rate of return on total capital is $5.4 \%$ in 2010 and $10 \%$ in 2015 , significantly contribute to the profitability of the business of the insurance sector. Earnings mainly come from insurance business, as indicated by the magnitude of the E4 indicator. However, during the 2010 crisis, insurance companies failed to secure earnings from any segment of their business. In a particularly bad position during this period were life insurance companies, which achieved a negative rate of return on total capital of $-11.5 \%$.

When it comes to business liquidity, fluctuations in average values of liquidity ratios indicate that insurance companies have sufficient liquid assets to settle short-term liabilities. The most liquid insurance companies are life insurance companies, while mixed insurance and non-life insurance companies showed lower levels of liquidity than average. 
Based on these results, it can be concluded that the business of the insurance companies observed varies significantly depending on the type of insurance, the analyzed aspect of the business, but also the observation period. In order to group insurance companies by performance, we will use cluster analysis, which will be presented below in this paper. Due to the large number of financial stability and business performance indicators, we will first reduce their numbers by using principal component analysis.

\subsection{RESEARCH METHODOLOGY AND DATA PROCESSING}

Principal component analysis (PCA) is a method of multivariate analysis that is used to reduce the dimension of a data set while maintaining the maximum possible variability present in that data. Therefore, in this paper, PCA is used to discover the hidden structure of financial stability indicators of insurance companies and to identify key internal factors of financial stability.

Bartlett's test of sphericity checks the hypothesis that correlation matrix is an identity matrix, which would indicate that selected values (less than 0.05) of the significance level indicate that a factor analysis may be useful with selected data. The achieved values of test statistics (See Table 4) indicate that data are suitable for implementation of factor analysis.

Table 4

Bartlett's test of sphericity results

\begin{tabular}{lccc}
\hline \multirow{2}{*}{ Test } & \multicolumn{3}{c}{ Bartlett's test of sphericity } \\
\cline { 2 - 4 } & $\mathbf{2 0 0 5}$ & $\mathbf{2 0 1 0}$ & $\mathbf{2 0 1 5}$ \\
\hline Statistics & 507.821 & 255.860 & 216.016 \\
\hline DF & 78 & 78 & 78 \\
\hline p-value & 0.0000 & 0.0000 & 0.0000 \\
\hline Note. Authors' calculations & & &
\end{tabular}

Table 5 shows the estimated factor loadings after varimax rotation. Only those factors whose eigenvalue is greater than 1 , or that explain more than $10 \%$ of the variance, were retained in the analysis. As a result of the assumptions made in this way, only 3 factors will be used in the analysis of the financial stability of insurance companies in 2005 and 2010, and in 2015, 4 factors will be used. The factors thus determined explain $73.14 \%$ of variability in 2005 , about $80 \%$ in 2010 and $85.41 \%$ of variability in 2015 in data. 
Table 5

Component loadings after varimax rotation

\begin{tabular}{|c|c|c|c|c|c|c|c|c|c|c|}
\hline \multirow{2}{*}{ Comp. } & \multicolumn{3}{|c|}{2005} & \multicolumn{3}{|c|}{2010} & \multicolumn{4}{|c|}{2015} \\
\hline & $F 1$ & $F 2$ & $F 3$ & $F 1$ & $F 2$ & $F 3$ & $F 1$ & $F 2$ & $F 3$ & F4 \\
\hline $\mathrm{C} 1$ & -0.69 & -0.00 & 0.59 & -0.46 & -0.58 & 0.34 & -0.32 & -0.43 & -0.70 & 0.24 \\
\hline $\mathrm{C} 2$ & 0.95 & -0.06 & -0.22 & 0.41 & 0.80 & -0.10 & -0.30 & 0.82 & 0.22 & 0.11 \\
\hline C3 & 0.98 & -0.05 & 0.11 & 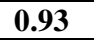 & 0.31 & -0.08 & -0.17 & 0.94 & 0.14 & 0.07 \\
\hline $\mathrm{A} 1$ & -0.17 & 0.24 & 0.01 & 0.40 & 0.43 & 0.68 & 0.29 & -0.03 & -0.31 & 0.76 \\
\hline A2 & -0.13 & 0.83 & -0.24 & -0.01 & 0.77 & -0.09 & 0.60 & 0.60 & -0.09 & -0.24 \\
\hline $\mathrm{A} 3$ & 0.078 & -0.08 & -0.06 & -0.15 & 0.87 & 0.16 & 0.22 & -0.07 & -0.24 & -0.73 \\
\hline R1 & -0.05 & -0.10 & 0.87 & -0.02 & -0.17 & 0.65 & 0.35 & -0.65 & 0.47 & 0.32 \\
\hline M3 & 0.78 & 0.01 & 0.26 & 0.96 & 0.21 & -0.09 & 0.58 & 0.65 & 0.41 & 0.15 \\
\hline E4 & 0.13 & 0.89 & -0.13 & 0.98 & 0.07 & 0.14 & 0.85 & -0.13 & -0.21 & 0.02 \\
\hline E5 & -0.03 & $\begin{array}{l}0.92 \\
\end{array}$ & -0.13 & 0.95 & 0.10 & 0.21 & 0.96 & -0.19 & 0.01 & 0.04 \\
\hline E8 & 0.40 & -0.74 & -0.16 & $\begin{array}{l}-0.72 \\
\end{array}$ & 0.18 & -0.23 & -0.95 & 0.11 & -0.10 & -0.07 \\
\hline L1 & 0.82 & -0.21 & 0.11 & 0.70 & 0.48 & -0.39 & 0.00 & 0.34 & 0.89 & 0.19 \\
\hline $\mathrm{L} 2$ & 0.25 & -0.21 & 0.81 & $\mathbf{0 . 8 0}$ & -0.04 & -0.46 & -0.27 & -0.16 & 0.89 & -0.06 \\
\hline $\begin{array}{c}\delta^{2} \\
(\%)\end{array}$ & 35.73 & 22.88 & 14.53 & 49.95 & 18.31 & 11.50 & 29.56 & 28.05 & 17.25 & 10.55 \\
\hline
\end{tabular}

Note. Authors' calculations.

We use the varimax factor rotation method to minimize the number of variables that have high loadings on a factor. Varimax rotation provides results that show the relationship of each variable to the factor. Variables with large loadings for a given factor are highlighted in bold. Based on these results, it can be concluded that the financial stability factors of the insurance companies varied over the period considered.

In the initial period, the financial stability of insurance companies was largely conditioned by the adequacy of capital and the quality of management. The second factor is the earning capacity and profitability, while the extent to which risks are transferred to reinsurance and the level of liquidity is the third factor of the financial stability of insurance companies. In 2010, which was identified as a period of economic and financial crisis, the importance of certain aspects of the business of insurance companies for their financial stability changed. Thus, the greatest influence on the financial stability of these companies has the quality of management, earning capacity and profitability and liquidity. The factor determined by these indicators explains about $50 \%$ of the variability in the business of insurance companies. Capital adequacy and asset quality determine $18.31 \%$ of the variability in the business of insurance companies, with the retention of premiums in self-retaining negatively affecting the business performance in this period. The least important factor is the decision to transfer risks to reinsurance, which largely determines the third factor of the financial stability of insurance companies. In the post-crisis period, during 
2015, the financial stability of insurance companies is defined by 4 determinants. Depending on the financial indicators that determine these factors, we can conclude that the variability of the financial stability is largely determined by their profitability. The second factor is largely determined by capital adequacy and quality of management, while the liquidity, which determines the third factor, explains $17.25 \%$ of the variability of the financial stability of the insurance companies observed. The asset management method, which largely determines the fourth factor, explains $10.55 \%$ of the performance variability of insurance companies.

By identifying the major components, the set of variables can be transformed, so that insurance companies will be grouped according to similarities in business based on PCA scores instead of original data. Cluster analysis will be used for grouping and the used closeness measure is the Euclidean distance (Danielsson, 1980). Depending on how the objects are grouped together, two approaches to cluster analysis can be distinguished: non-hierarchical and hierarchical (Kaufman \& Rousseeuw, 2009). The most common nonhierarchical analysis method is the $k$-means method. In order to determine the optimal number of clusters, the maximum value of the Silhouette coefficient (Rousseeuw, 1987) for the Euclidean distance was used in this work. The silhouette coefficient is a measure for the clustering quality. The values of this coefficient between 0.7 and 1.0 indicate clustering results with excellent separation between clusters, while the values from 0.5 to 0.7 evidencesthat objects are clearly assigned to clusters (Table 6).

Table 6

Silhouette coefficients for 2005, 2010 and 2015

\begin{tabular}{lcccc}
\hline $\begin{array}{l}\text { Number of } \\
\text { clusters }\end{array}$ & $\mathbf{2}$ & $\mathbf{3}$ & $\mathbf{4}$ & $\mathbf{5}$ \\
\hline 2005 & $\mathbf{0 . 6 2}$ & 0.55 & 0.55 & 0.48 \\
\hline 2010 & 0.67 & $\mathbf{0 . 6 9}$ & 0.63 & 0.58 \\
\hline 2015 & 0.59 & $\mathbf{0 . 7 6}$ & 0.76 & 0.67 \\
\hline
\end{tabular}

Note. Authors' calculations.

The maximum value of this coefficient in the first case (2005) indicates that the optimum number of clusters is two, in the second case (2010) three, while in the third case (2015) the maximum value is reached for 4 clusters (Table 6). 


\section{DISCUSSION OF RESEARCH RESULTS}

Based on the results of clustering, it can be concluded that insurance companies in the Republic of Serbia have undergone some changes in financial stability over the observed period. In 2005, after significant changes to the institutional framework in the insurance sector, the analyzed insurance companies could be classified into 2 clusters according to the degree of financial stability.

The first cluster of insurance companies consists of 5 insurance companies: AMS Insurance, DDOR Novi Sad, Generali Insurance Serbia, Dunav Insurance, UNIQA Insurance. This cluster includes insurance companies that are classified as the largest insurance companies by the value of their balance sheet assets and premiums collected. A comprehensive analysis of business performance indicates that these insurance companies retained a relatively high risk from performing insurance operations in the observed period, given that the average value of the capital adequacy ratio is $\mathrm{C} 1=2.067$ and $\mathrm{C} 3=0.595$. On the other hand, the relatively low average value of $\mathrm{C} 2=0.341$ is a signal that these companies were more exposed to market, investment and credit risk. The inadequate quality of the management structure (average value M3 $=0.065$ ) was reflected in the reinsurance policy, which in these companies was so conceptualized that on average about $80 \%$ of the insured risks were retained (average value $\mathrm{R} 1=0.788$ ). Nevertheless, adequate asset management contributed to ensuring the profitability (average value of E5 $=0.784$ ) and maintaining liquidity (average value of $\mathrm{L} 1=0.124$ and $\mathrm{L} 2=2.033$ ) of these insurance companies.

The second cluster of insurance companies consists of 7 insurance companies: Globos Insurance, Grawe Insurance, Millennium Insurance, Triglav Insurance, Energoprojekt Garant, Sava Insurance, Wiener Städtische Insurance. Of the high-ranking insurance companies by value and balance sheet assets, only Wiener Städtische Insurance is in this group. In terms of capital adequacy, this group of companies is characterized by the inability to generate an insurance portfolio. The low average value of the indicator $\mathrm{C} 1=0.609$, on the one hand, and the large average value of the indicator $\mathrm{C} 3=2.479$, on the other, show that companies did not use their capital resources in this period of operation. In terms of asset structure, compared to the previous group, these companies invested less in intangible assets, real estate and non-traded securities (average value $\mathrm{A} 1=0.249$ ), and more in equity participation in other legal entities (average value $\mathrm{A} 3=0.235$ ). The quality of management structure decisions (average value $\mathrm{M} 3=0.085$ ) contributed to maintaining the profitability of the business at the level of the previous group (average value E5 $=0.747$ ), as well as high level of liquidity (average values L1 $=0.552$ and L2 $=1.973$ ). 
During the crisis period, 3 clusters of insurance companies can be identified. The first cluster consists of 7 insurance companies: AMS Insurance, DDOR Novi Sad, Generali Insurance Serbia, UNIQA non-life insurance, Wiener Städtische Insurance, Sava Insurance, Triglav Insurance. This cluster also contains the three largest insurance companies in the Republic of Serbia. Due to inadequate business risk management in the previous period, companies in this cluster increased their exposure to insurance risk during the crisis, as indicated by the average values of capital adequacy indicators $\mathrm{C} 1=2.694$ and $\mathrm{C} 3=$ 0.261 . The financial crisis, whose effects also spread to emerging markets, led to an increase in these companies' exposure to market, investment and credit risk (average $\mathrm{C} 2=0.181$ ). In an effort to reduce the investment risk, the insurance companies significantly changed the structure of their assets in this period, so the participation of intangible assets, real estate and securities in the market decreased and it averaged $24.1 \%$, the collection of receivables accelerated on the basis of the insurance premium (average value A2 $=0.184$ ), and the share in the equity of other legal entities amounted to only $2.7 \%$. = 0.858 ). The quality of the management structure also declined (average M3 = 0.056 ), as did profitability (average $\mathrm{E} 5=0.856$ and $\mathrm{E} 8=0.035$ ) and liquidity (average $\mathrm{L} 1=0.226$ and $\mathrm{L} 2=1.278$ ) of insurance companies.

The second cluster consists of 6 insurance companies: Globos Insurance, Grawe Insurance, Energoprojekt Garant, Dunav Insurance, Sava Life Insurance, UNIQA Life Insurance. The largest number of companies that were also classified in the second cluster in the previous period retained their place in the same group, and among them is one of the largest insurance companies - Dunav Insurance. Even in times of crisis, these societies are characterized by the inability to use capital resources given the low average values of the indicators $\mathrm{C} 1=0.647$ and $\mathrm{C} 3=3.243$. However, the exposure to other risks was reduced (average $\mathrm{C} 2=0.485$ ) due to a decrease in equity participation of other legal entities (average A3 $=0.112$ ) and an acceleration of claims collection (average $\mathrm{A} 2=0.217)$. In contrast, investments in long-term assets - real estate, intangible assets and non-traded securities - increased (average value A1 $=0.271$ ). These companies are characterized by a high level of quality of the management structure (average value M1 $=0.232$ ), which could not find a way to further reduce the risk of reinsurance business during this period, since the average value of R1 increased to 0.883 . The inability to use capital resources and the reduced investment opportunity during this period resulted in a drastic decrease in profitability (average value E5 $=1.185$ and E8 $=0.024$ ) and an increase in liquidity (average value L1 $=0.584$ and L2 $=5.111$ ) of these insurance companies. 
Millennium Insurance stands out in a separate cluster. Compared to the previous two clusters of insurance companies, this company has a moderate level of performance in every aspect of the business.

In the post-crisis recovery period, in 2015, according to the degree of financial stability, insurance companies in the Republic of Serbia could be classified into 4 clusters. Such inconsistency points to the fact that insurance companies did not recover from the effects of the crisis in the same way or at the same speed.

The first cluster consists of 3 insurance companies: AMS Insurance, DDOR Novi Sad and Millennium Insurance. In the period after the crisis, these companies are characterized by the inadequacy of the total capital with respect to the assumed risks under the insurance contracts (average value of indicators $\mathrm{C} 1=3.745$ and $\mathrm{C} 3=0.522$ ) and high exposure to other risks (average value of indicators $\mathrm{C} 2=0.223$ ), especially investment, due to the fact that the assets of these companies are dominated by long-term holdings and illiquid assets (average value of indicator $\mathrm{A} 1=0.452$ ). The share of claims on the collection of insurance premiums in assets is on average $5.1 \%$, while the share in the capital of other legal entities is at a negligible level (average value A3 $=0.003$ ). In reinsurance, these companies transfer only $10 \%$ of the assumed risks on average and as a result of business and investment activities earn an average return of $10.8 \%$ (average value E5 $=0.892$ ). The first and second degree liquidity is not satisfactory (average $\mathrm{L} 1=0.083$ and $\mathrm{L} 2=1.395$ ).

The second cluster also includes 3 insurance companies: Generali Insurance Serbia, Wiener Städtische Insurance and UNIQA life insurance. These companies are also characterized by the inadequacy of total capital with respect to the assumed business risks (average value of indicators $\mathrm{C} 1=1.814$ and $\mathrm{C} 3=$ 0.218 ) and high exposure to other risks (average value of indicators $\mathrm{C} 2=$ 0.155). The assets are structured so that the dominant share is held by real estate, intangible assets and non-traded securities with $33.7 \%$. The share of premium receivables averages $9.8 \%$, while investments in securities of other companies do not exceed $2.8 \%$ of the total value of assets. These companies carry an average of $14 \%$ of the risks assumed in reinsurance, providing significantly higher profitability compared to the companies in the previous cluster (average value of indicators E5 $=0.483$ and E8 $=0.176$ ). Current liquidity is not satisfactory (average value of indicator L1 $=0.220$ ), but shortterm liabilities in current business are covered on average by RSD 5,680 shortterm assets.

The third cluster consists of 4 insurance companies, namely: Globos Insurance, Grawe Insurance, Energoprojekt garant and Sava Life Insurance. This group of companies is also characterized by inadequate capital management (average 
values of $\mathrm{C} 1=2.132$ and $\mathrm{C} 3=0.614)$ and exposure to market, investment and credit risk (average value of $\mathrm{C} 2=0.227$ ). Assets are on average structured as follows: the share of long-term illiquid assets is $36.9 \%$, the share of insurance premium claims is $11.8 \%$ and the share in the capital of other legal entities is $3.4 \%$. These insurance companies, on average, transfer $18.7 \%$ of the assumed risks into reinsurance, but they achieve their profitability mainly on the basis of investment activities (average value of indicators $\mathrm{E} 4=1,000$ and $\mathrm{E} 5=0.929$ ). The current liquidity ratio is very low (average $\mathrm{L} 1=0.061$ ) and the average liquidity ratio is 1.343 .

The fourth cluster consists of 4 insurance companies: Triglav Insurance, Dunav Insurance, Sava non-life insurance and UNIQA non-life insurance. In contrast to the companies in other clusters, these insurance companies also face the inability to generate an adequate insurance portfolio (average value of indicators $\mathrm{C} 1=0.399$ and $\mathrm{C} 3=1.764$ ), as well as the problem of collecting claims from insurance business (average value of indicator A2 $=0.161$ ). However, compared to other companies, they are not significantly exposed to other risks (average $\mathrm{C} 2$ value $=0.364$ ). Inadequate asset structure (average investment in intangible assets, real estate and non-traded securities is $28.4 \%$ and investment in capital of other legal entities only $0.7 \%$ ), as well as retention of assumed risks from insurance business (average value of $\mathrm{R} 1=0.930$ ), represent the basic factors for the unprofitable business of these companies (average value of indicators E5 = 1.420 and $\mathrm{E} 8=-0.148)$. On the other hand, these companies are characterized by an extremely high level of current liquidity (average value of L2 $=23.807$ ), which is a consequence of inadequate management decisions, because despite the highest allocations for workers' earnings compared to other insurance companies (average value of M1 $=0.154$ ), the expected effects of the work are absent.

\section{CONCLUSION}

Monitoring the effectiveness of implementing insurance companies' business strategies is made possible by the existence of an integrated system of financial and non-financial performance measures. The multidimensional system of performance measures provides insights into various aspects of the business of insurance companies and meets the information requirements of a large number of different stakeholders. By identifying strategic priorities, outcomes and drivers of performance, one can identify the need to reengineer business processes, so the strategic and operational control process is the "driver of change" of business operations. 
The analyzed framework of performance measures in the Republic of Serbia the CARMEL framework, enables to look at the success of the business of insurance companies from different aspects. Rating and ranking of insurance companies cannot be done on the basis of partial indicators, but involves defining the score based on the achieved performance in all aspects of the business. In this paper, a comprehensive analysis of the performance of insurance companies operating in the Republic of Serbia in 2005, 2010 and 2015 is performed using principal component analysis and $k$-means data mining algorithm. Based on the results obtained, key internal factors for the financial stability of insurance companies under different economic conditions were identified in one specific emerging market. In the initial analysis period or the period after the introduction of significant regulatory reforms in the insurance sector in the Republic of Serbia, the financial stability of insurance companies was conditioned to a large extent by capital adequacy and quality of management. In 2010, which was identified as the period when the effects of the financial crisis could be observed, the importance of certain aspects of the business of insurance companies for their financial stability has changed. Thus, the greatest impact on the financial stability of insurance companies is the quality of management, but also the earning capacity and profitability and liquidity. In the post-crisis period, that is, in 2015, the variability of the financial stability of insurance companies was largely determined by their profitability.

Depending on the performance achieved in certain aspects of the business, insurance companies are divided into several groups, which confirm the main hypothesis of this research study. In the initial observation period, all insurance companies could be classified into two clusters. The crisis period (2010) did not significantly affect the classification of insurance companies - all companies could still be divided into two clusters in accordance with the achieved performance, with Millennium Insurance Belgrade remaining unallocated into identified clusters. Post-crisis recovery has more clearly differentiated insurance companies operating in the Republic of Serbia, so that in this period we can distinguish four clusters of insurance companies. If the classification obtained in this way is compared with the rankings offered by the NBS based on the value of the balance sheet assets and the value of premiums paid, it can be concluded that the largest insurance companies are not the most successful in all economic conditions. Inadequate capital management, as well as the inability to generate insurance and investment portfolios, in some periods has led to a drastic decrease in the profitability of these insurance companies. Their business operations were generally stable over the period considered, and these insurance companies managed to maintain their position in the market, but were not equally successful in all aspects. Some of these aspects of the business can even permanently threaten financial stability. 
Although the results obtained may be considered relevant, the unavailability and inadequacy of disclosure of information about the business of insurance companies in the period considered were fundamental in limitations for the more detailed and accurate analysis. Therefore, it can be concluded that in order to improve the presented clustering models, access to all information on the business of insurance companies is necessary, referring to analytical data that would allow the inclusion of additional indicators relevant to the ranking. Given the impossibility of adequately assessing individual business segments solely on the basis of the proposed set of indicators, future research will consider additional indicators, both financial and non-financial, with regard to management quality assessment.

\section{REFERENCES}

Almajali, A. Y., Alamro, S. A., \& Al-Soub, Y. Z. (2012). Factors affecting the financial performance of Jordanian insurance companies listed at Amman Stock Exchange. Journal of Management research, 4(2), 266-289.

Banker, R. D., Janakiraman, S. N., \& Konstans, C. (2001). Balanced scorecard: linking strategy to performance. Financial Executives Research Foundation.

Bawa, S. K., \& Chattha, S. (2013). Financial performance of life insurers in Indian insurance industry. Pacific Business Review International, 6(5), 44-52.

Camarero, C. (2007). Relationship orientation or service quality? What is the trigger of performance in financial and insurance services?. International Journal of Bank Marketing, 25(6), 406-426.

Cummins, J. D., Dionne, G., Gagné, R., \& Nouira, A. H. (2009). Efficiency of insurance firms with endogenous risk management and financial intermediation activities. Journal of Productivity Analysis, 32(2), 145-159.

Danielsson, P. E. (1980). Euclidean distance mapping. Computer Graphics and image processing, 14(3), 227-248.

Das, M. U. S., Podpiera, R., \& Davies, N. (2003). Insurance and issues in financial soundness (No. 3-138). International Monetary Fund.

Felício, J. A., \& Rodrigues, R. (2015). Organizational factors and customers' motivation effect on insurance companies' performance. Journal of Business Research, 68(7), 1622-1629. 
Ittner, C. D., Larcker, D. F., \& Randall, T. (2003). Performance implications of strategic performance measurement in financial services firms. Accounting, organizations and society, 28(7-8), 715-741.

Kaplan, R. S., \& Norton, D. P. (2001). The strategy-focused organization: How balanced scorecard companies thrive in the new business environment. Harvard Business Press.

Kasturi, R. (2006). Performance management in insurance corporation. Journal of Business Administration online, 5(1), 1-15.

Kaufman, L., \& Rousseeuw, P. J. (2009). Finding groups in data: an introduction to cluster analysis (Vol. 344). John Wiley \& Sons.

Kočović, J., Paunović, B., \& Jovović, M. (2014). Determinants of business performance of non-life insurance companies in Serbia. Ekonomika preduzeća, 62(7-8), 367-381.

Lee, C. C., \& Lin, C. W. (2016). Globalization, political institutions, financial liberalization, and performance of the insurance industry. The North American Journal of Economics and Finance, 36, 244-266.

Lee, C. C., Chang, C. H., Arouri, M., \& Lee, C. C. (2016). Economic growth and insurance development: The role of institutional environments. Economic Modelling, 59, 361-369.

Lillian, M. (2010). The relationship between corporate governance, ownership structure and financial performance of insurance companies in Kenya. School of Business, University of Nairobi.

Linnerooth-Bayer, J., \& Mechler, R. (2015). Insurance for assisting adaptation to climate change in developing countries: a proposed strategy. In Climate Change and Insurance (pp. 29-44). Routledge.

Lu, W. M., Wang, W. K., \& Kweh, Q. L. (2014). Intellectual capital and performance in the Chinese life insurance industry. Omega, 42(1), 65-74.

Malik, H. (2011). Determinants of insurance companies profitability: an analysis of insurance sector of Pakistan. Academic Research International, 1(3), 315-321.

NBS (2005). Annual reports "Insurance sector in Serbia". Republic of Serbia: National Bank of Serbia.

NBS (2010). Annual reports "Insurance sector in Serbia". Republic of Serbia: National Bank of Serbia. 
22 | RESEARCH ON INTERNAL INDICATORS OF FINANCIAL STABILITY OF INSURANCE COMPANIES IN THE REPUBLIC OF SERBIA

NBS (2015). Annual reports "Insurance sector in Serbia". Republic of Serbia: National Bank of Serbia.

NBS (2015). Decision on the Management System of an (Re)Insurance

Company. Republic of Serbia: National Bank of Serbia.

NBS (2016). CARMEL indicators of insurance companies' operations with the framework guidelines for their interpretation. Republic of Serbia: National Bank of Serbia.

NBS (2017). Annual reports "Insurance sector in Serbia". Republic of Serbia: National Bank of Serbia.

NBS (2018). Decision on the Management System of an (Re)Insurance Company. Republic of Serbia: National Bank of Serbia.

Petrović, E., \& Stanković, J. Z. (2018). Economic determinants of insurance demand in the Republic of Serbia. In Kočović, J. et al. (Eds.), Insurance in the Post-crisis Era (pp. 135-153). Belgrade, Serbia: University of Belgrade, Faculty of Economics Publishing Centre.

Rousseeuw, P. J. (1987). Silhouettes: a graphical aid to the interpretation and validation of cluster analysis. Journal of computational and applied mathematics, 20, 53-65.

Smajla, N. (2014). Measuring Financial Soundness of Insurance Companies By Using Caramels Model-Case Of Croatia. Interdisciplinary Management Research, 10, 600-609.

Yu, C. P. (2015). Financial policies on firm performance: The US insurance industry before and after the global financial crisis. Economic Modelling, 51, 391-402.

Zarina, I., Voronova, I., \& Pettere, G. (2018). Assessment of the Stability of Insurance Companies: The Case of Baltic Non-Life Insurance Market. Economics and Business, 32(1), 102-111.

Delivered: 15.07.2020.

Accepted: 15.02.2021. 